\title{
Motivational factors influencing labour productivity in the handicrafts \& cottage industries of Odisha, India.
}

\author{
Satya Ranjan Nayak ${ }^{1}$, Dr. Sudhakar Patra ${ }^{2}$, Madhusmita Samal ${ }^{3}$ \\ ${ }^{1}$ Faculty of Economics and Business Administration, Gandhi Institute for Technological Advancement, \\ Bhubaneswar, At: Badaraghunathpur, Po: Madanpur Dist: Khordha, Odisha., India, Pin: 752054 \\ ${ }^{2}$ Professor of Economics, Ravenshaw University, Cuttack, Odisha, India \\ ${ }^{3}$ Asst. Prof. in Economics, Gandhi Institute for Technological Advancement, Bhubaneswar, Odisha., India
}

\begin{abstract}
The productivity of labour is an indispensable condition for the prosperity of enterprises and the well being of the workers and their families. While the production facilities at workplace and the remuneration are important, attitudes towards work, and the value placed by the society on dignity of labour are equally important in influencing the productivity of labour. This paper tries to identify the factors that promote positive motivational behaviour among the workers as to improve production in the industries on the basis of primary data collected from 300 respondents $($ male $=180$, female $=120)$, randomly selected in 10 handicrafts \& cottage industries of Odisha, one of the state of India. Furthermore the study will identify the satisfaction and dissatisfaction level of employees in the handicrafts \& cottage industries of Odisha, since these are important characteristics in the workplace. Findings suggest that there is a direct and positive relationship between motivational factors as human resource policy, allowances, labour welfare measures and job satisfaction and job relation with the labours' productivity level. So, a provision for better wage and salary structure, regular promotion, assurance of adequate job security and bonus for excellent performance as well as proper time to time training and education are the important factors for the growth and development of handicrafts \& cottage industries of Odisha,
\end{abstract}

Keywords: labour productivity, human resource policy, job security, non-monetary incentives, working environment.

JEL Classification: J01, J24

\section{Introduction:}

Productivity consciousness has acquired worldwide momentum. Higher productivity is necessary for the survival of any nation. It stands for proper utilisation of available resources to achieve the best results with minimum cost. Improvement in productivity is the only answer to the problems in the industrial sphere and it is the only path to national prosperity. In India it assumes special significance owing to the resource gap. In order to overcome the hurdle of shortfall in resources, stepping up of productivity is a must.

Particularly, the state of Odisha's economy in recent years has been led by high growth in the industrial sector. This sector has averaged real annual growth rate of $12.56 \%$, at 2004-05 prices, during the first three years of the $11^{\text {th }}$ Five Year Plan (2007-10). It is also encouraging to note that the number of small scale industry (SSI) and Micro, Small and Medium Enterprises (MSME) units, and total investments therein increasing over the years. But, the growth of some traditional MSMEs in particular the handicrafts \& cottage industries are deteriorating in every respect like no. of units established, investment and employment generation.(Ref. Table1)

TABLE: 1 Growth Of Handicrafts \& Cottage Industries Of Odisha, India

\begin{tabular}{|l|l|l|l|}
\hline Year & No. of units established & $\begin{array}{l}\text { Investment } \\
\text { (Rs.in Crore) }\end{array}$ & $\begin{array}{l}\text { Employment generated } \\
\text { (no. of persons) }\end{array}$ \\
\hline $2000-01$ & 22,431 & 40.65 & 37,641 \\
\hline $2001-02$ & 26,196 & 61.72 & 36,937 \\
\hline $2002-03$ & 25,041 & 61.34 & 39,528 \\
\hline $2003-04$ & 23,287 & 67.87 & 39,743 \\
\hline $2004-05$ & 18,277 & 48.41 & 30,052 \\
\hline $2005-06$ & 13,363 & 39.42 & 22,734 \\
\hline $2006-07$ & 13,063 & 53.32 & 20,605 \\
\hline $2007-08$ & 9,011 & 38.3 & 15,368 \\
\hline $2008-09$ & 8,994 & 34.83 & 15,279 \\
\hline
\end{tabular}

Source: Directorate of Handicrafts and Cottage Industries of Odisha \& Economic Survey, Odisha: 2009-10 
So, from the above table it is almost clear that the growth of handicraft and cottage industry of Odisha is in a decreasing state only due to gradual decline of labour productivity and for large labour turnover. Therefore, an attempt has been made to find out what are the motivational factors which can improve labour productivity of these said industries.

\section{Review of Literature:}

Dr.Sucharitha, Dr.J.U.Maheswar Reddy, and Dr.Reecharanjansingh(2012) ${ }^{1}$ in their study found that It is the quality of the employee's workplace environment that most impacts on their level of motivation and subsequent performance. How well they engage with the organization, especially with their immediate environment, influences to a great extent their error rate, level of innovation and collaboration with other employees, absenteeism and ultimately, how long they stay in the job. Creating a work environment in which employees are productive is essential to increased profits for your organization, corporation or small business.

Navdeep Kumar, Pankaj $\operatorname{Garg}(2011)^{7}$ indicated that there is a statistical significant relationship between the three independent variables (salary, facilities and promotion) with dependent variable i.e. job satisfaction as well as the productivity. The results also depicted that among independent variables, salary package is the most important and more influential variable.

Daljeet Singh Wadhwa, Manoj Verghese, Dalvinder Singh Wadhwa $(2011)^{9}$ focused on how to motivate employees to work more productively and to increase their feelings of satisfaction, involvement, and commitment. They also found out that all the three variables that are environmental, organizational and behavioral factors have a positive impact on job satisfaction and improvement in their productivity. It means that if the employees are treated equally and fairly and they are properly supervised, their level of satisfaction can be increased towards their job.

Mohammed Javed Kalburgi and Dinesh.G.P (2010) ${ }^{4}$ viewed that employees were highly motivated due to good working environment \& highly supported by supervisors to perform the task and also the workers were positively affected toward higher productivity with the provision of regular promotion, assurance of adequate job security and bonus for excellent performance. Nevertheless monetary incentives and rewards do not exert stronger influence on workers than any form of motivational factor. The organisation should encourage initiative and creativity by allowing for some flexibility in application of rules and regulation.

Dale S. Rose, Stuart D. Sidle and Kristin H. Griffith $(2007)^{2}$ in their study of monetary incentives found out that there was significant improvement in employees' response rate with increased incentives.

Lawler $(2003)^{5}$ noted that different theories questioning why people prefer certain careers, why they seek particular rewards and why they feel satisfied or dissatisfied with their work and rewards. These are some of the resonating questions that create so many assumptions and hypotheses to be researched. It is important to review the literature on motivation clarify the issues.

Sharma $(1991)^{8}$ referring to the report of the National Commission of Labour, "under Indian conditions incentives were concerned with effective utilization of manpower which is quickest, cheapest and surest means of increasing productivity and stimulate human efforts to provide positive motivation to greater output."

Matthew $(1983)^{6}$ stated, direct monetary benefits coupled with greater responsibility and autonomy in decision making were good motivators than other perks. However, the non-monetary incentives are perhaps more important in the case of executives, particularly those in higher position.

Gupta $(1975)^{3}$ in his study of labour incentive in Indian Iron and Steel Industry found that monetary incentives are best motivators which lead to better motivation and a higher labour productivity.

\section{Statement of the problem:}

Motivation is defined as the process that account for an individual's intensity, direction, and persistence of effort toward attaining a goal. It is motivation that energies the behavior of people, while behavior activates action \& action leads to achievement. It is an important function of management to motivate the people working in industries to perform the work assigned effectively \& efficiently. The organized labours have tried to interpret productivity as the value of all output divided by man-hours of work. This assumption is based on the promise that the labors are more productive, tried to time spent in producing a unit of output is higher than in a situation where this ratio is lower. The important factors that influence the production \& productivity of labor are

I. Ability of the worker

II. Willingness of worker \&

III. The environment under which he has to work.

In case of handicrafts \& cottage industries of Odisha, where most of the employers don't believe much in effective employee's satisfaction and motivation to ensure higher performance as well as higher labour productivity. So, that the growth of the said industries is going to be declining day by day. 
3.1 Purpose of the study:

- To evaluate and identify the relationship between monetary and non-monetary incentives offered on employee motivation and job satisfaction.

- To study the job interest and involvement factor from the labours point of view.

- To understand workers' perception of various incentives (Allowances, Labour welfare measures) offered to them as a tool towards improvement of their productivity.

- To suggest improvements in incentive schemes package for effective operation of Micro, Small and Medium Enterprises (MSME), Odisha, particularly Handicrafts \& Cottage industries of Odisha.

\section{Research Methodology:}

This study used both primary data and secondary data. Primary data was collected by distributing questionnaire to the labours of the handicraft and cottage industries of the state of Odisha, India. The sample of the study was consisted of 300 respondents (male $=180$, female $=120$ ), randomly selected in 10 handicrafts $\&$ cottage industries of Odisha, one of the state of India. Before giving the questionnaires, all questions were explained to the participants so they could easily complete the questionnaire and the relevant results. Only one questionnaire was given to each respondent. In the first part of the questionnaire, the nature and the purpose of the work were explained and the assurances of complete secrecy of identity and responses of the respondents were given. Also some background information such as age, marital status, designation was asked. In the second part there were close ended questions each on Likert's five-point scale. . There was an open ended question for suggestion or remarks in the end with thanks note. The secondary data was collected from different Economic Survey of Odisha, Annual Survey of Industries, various journals, and websites to the relevant subject matter under the study.

With a view to achieving the objectives set for the study, the researcher has used combination of exploratory and descriptive research.

\section{Analysis and Interpretation:}

Major Factors which motivates labours for higher productivity is classified into four categories as

A. Human resource policy

B. Allowances

C. Labour welfare measures

D. Job interest \& involvement factor

TABLE: 2 Human Resource Policies Which Influence Labour Productivity

\begin{tabular}{|l|l|l|l|l|l|l|}
\hline $\begin{array}{l}\text { Human } \\
\text { resource } \\
\text { policy }\end{array}$ & $\begin{array}{l}\text { Highly } \\
\text { Dissatisfied }\end{array}$ & Dissatisfied & $\begin{array}{l}\text { Moderately } \\
\text { Satisfied }\end{array}$ & Satisfied & $\begin{array}{l}\text { Highly } \\
\text { Satisfied }\end{array}$ & Total \\
\hline $\begin{array}{l}\text { Wages \& } \\
\text { salary } \\
\text { structure }\end{array}$ & $\mathbf{3 5}$ & $\mathbf{9 2}$ & $\mathbf{1 1 5}$ & $\mathbf{4 0}$ & $\mathbf{1 8}$ & $\mathbf{3 0 0}$ \\
\cline { 2 - 7 } Promotion & $\mathbf{8 5}$ & $\mathbf{3 0 . 6 6 \%}$ & $\mathbf{3 8 . 3 3 \%}$ & $\mathbf{1 3 . 3 3}$ & $\mathbf{6 \%}$ & $\mathbf{1 0 0 \%}$ \\
\cline { 2 - 7 } & $\mathbf{2 8 . 3 3 \%}$ & $\mathbf{5 1 . 3 3 \%}$ & $\mathbf{1 4 \%}$ & $\mathbf{4 . 6 6 \%}$ & $\mathbf{1 . 6 6 \%}$ & $\mathbf{1 0 0 \%}$ \\
\hline $\begin{array}{l}\text { Education \& } \\
\text { training }\end{array}$ & $\mathbf{5 5}$ & $\mathbf{1 3 2}$ & $\mathbf{8 3}$ & $\mathbf{2 2}$ & $\mathbf{8}$ & $\mathbf{3 0 0}$ \\
\cline { 2 - 7 } & $\mathbf{1 8 . 3 3 \%}$ & $\mathbf{4 4 \%}$ & $\mathbf{2 7 . 6 6 \%}$ & $\mathbf{7 . 3 3 \%}$ & $\mathbf{2 . 6 6 \%}$ & $\mathbf{1 0 0 \%}$ \\
\hline $\begin{array}{l}\text { Performance } \\
\text { appraisal }\end{array}$ & $\mathbf{9 0}$ & $\mathbf{1 3 6} \%$ & $\mathbf{4 7}$ & $\mathbf{2 0}$ & $\mathbf{7}$ & $\mathbf{3 0 0}$ \\
\cline { 2 - 7 } $\begin{array}{l}\text { Industry } \\
\text { policy } \\
\text { rules }\end{array}$ & $\mathbf{6 5}$ & $\mathbf{4 5 . 3 3 \%}$ & $\mathbf{1 5 . 6 6 \%}$ & $\mathbf{6 . 6 6 \%}$ & $\mathbf{2 . 3 3 \%}$ & $\mathbf{1 0 0 \%}$ \\
\cline { 2 - 7 } & $\mathbf{2 1 . 6 6 \%}$ & $\mathbf{4 0 . 6 6 \%}$ & $\mathbf{1 7 \%}$ & $\mathbf{1 4 \%}$ & $\mathbf{6 . 6 6 \%}$ & $\mathbf{1 0 0 \%}$ \\
\hline
\end{tabular}

Source: Primary data

The above table represents the satisfaction and dissatisfaction level of the labours those who are working under the said industries regarding human resource policy.

Wages and salary structure: It indicates that more than $42 \%$ of the respondents are overall dissatisfied where as only $13.33 \%$ of the respondents are satisfied with the wage and salary structure of the industries.

Promotion: In this area, more than $51.33 \%$ respondents are dissatisfied, where as only $20 \%$ of our respondents are overall satisfied regarding promotion rules and facility. 
Education \& training: Only 7.33\% of the respondents are satisfied regarding education, training and workshop provide by the industries to improve their productivity and capability. But, near about $40 \%$ of the respondents are dissatisfied regarding this education and training.

Performance appraisal: It indicates that $30 \%$ of the respondents are highly dissatisfied where as only $2.33 \%$ of the respondents are highly satisfied with the performance appraisal of the industries.

Industry policy\& rules: It reveals more than $60 \%$ of the respondents are both highly dissatisfied and dissatisfied whereas, only $17 \%$ of the respondents are moderately satisfied.

TABLE: 3 Allowances Which Influence Labour Productivity

\begin{tabular}{|c|c|c|c|c|c|c|}
\hline Allowances & $\begin{array}{l}\text { Highly } \\
\text { Dissatisfied }\end{array}$ & Dissatisfied & $\begin{array}{l}\text { Moderately } \\
\text { Satisfied }\end{array}$ & Satisfied & $\begin{array}{l}\text { Highly } \\
\text { Satisfied }\end{array}$ & Total \\
\hline \multirow{2}{*}{$\begin{array}{l}\text { Dearness } \\
\text { Allowances }\end{array}$} & 47 & 112 & 89 & 52 & NIL & 300 \\
\hline & $15.66 \%$ & 37.33\% & $29.66 \%$ & $17.33 \%$ & NIL & $100 \%$ \\
\hline \multirow[t]{2}{*}{ House Rent } & 34 & 128 & 80 & 41 & 17 & 300 \\
\hline & $11.33 \%$ & $42.66 \%$ & $26.66 \%$ & $13.66 \%$ & $5.66 \%$ & $100 \%$ \\
\hline \multirow{2}{*}{$\begin{array}{l}\text { Transport } \\
\text { Allowances }\end{array}$} & 124 & 96 & 61 & 11 & 9 & 300 \\
\hline & $41.33 \%$ & $32 \%$ & $20.33 \%$ & $3.66 \%$ & $3 \%$ & $100 \%$ \\
\hline \multirow{2}{*}{$\begin{array}{l}\text { Medical } \\
\text { Allowances }\end{array}$} & 47 & 135 & 92 & 20 & 6 & 300 \\
\hline & $15.66 \%$ & $45 \%$ & $30.66 \%$ & $6.66 \%$ & $2 \%$ & $100 \%$ \\
\hline \multirow{2}{*}{$\begin{array}{l}\text { Washing } \\
\text { Allowances }\end{array}$} & 72 & 110 & 90 & 20 & 8 & 300 \\
\hline & $24 \%$ & $36.66 \%$ & $30 \%$ & $6.66 \%$ & $2.66 \%$ & $100 \%$ \\
\hline
\end{tabular}

Source: Primary data

The above table represents the satisfaction and dissatisfaction level of the labours those who are working under the said industries regarding allowances, provided to them.

Dearness Allowances: It shows $37.33 \%$ of respondents are dissatisfied where as $17.33 \%$ respondents are dissatisfied with dearness allowances provided by the said industries.

House Rent: It denotes $42.66 \%$ of respondents are dissatisfied and a minimum of $13.66 \%$ respondents are dissatisfied with the house rent provided by the industries.

Transport Allowances: It indicates that $41.33 \%$ of the respondents are highly dissatisfied where as only $3 \%$ of the respondents are highly satisfied with the performance appraisal of the industries.

Medical Allowances: It reveals that near about $45 \%$ respondents are dissatisfied and only a minimum of $6.66 \%$ respondents are dissatisfied with the medical allowances provided by the industries.

Washing Allowances: On this criteria, more than $60 \%$ respondents are both highly dissatisfied and dissatisfied and on the other hand $6.66 \%$ respondents are satisfied with the allowances provided by the industries.

TABLE: 4 Welfare Measures Which Influence Labour Productivity

\begin{tabular}{|l|l|l|l|l|l|l|}
\hline $\begin{array}{l}\text { Welfare } \\
\text { Measures }\end{array}$ & $\begin{array}{l}\text { Highly } \\
\text { Dissatisfied }\end{array}$ & Dissatisfied & $\begin{array}{l}\text { Moderately } \\
\text { Satisfied }\end{array}$ & Satisfied & $\begin{array}{l}\text { Highly } \\
\text { Satisfied }\end{array}$ & Total \\
\hline \multirow{2}{*}{ Leave Facility } & $\mathbf{2 0}$ & $\mathbf{4 5}$ & $\mathbf{1 1 5}$ & $\mathbf{1 0 6}$ & $\mathbf{1 4}$ & $\mathbf{3 0 0}$ \\
\cline { 2 - 7 } & $\mathbf{6 . 6 6 \%}$ & $\mathbf{1 5 \%}$ & $\mathbf{3 8 . 3 3 \%}$ & $\mathbf{3 5 . 3 3 \%}$ & $\mathbf{4 . 6 6 \%}$ & $\mathbf{1 0 0 \%}$ \\
\hline \multirow{2}{*}{$\begin{array}{l}\text { Facility for } \\
\text { children } \\
\text { education }\end{array}$} & $\mathbf{1 6 4}$ & $\mathbf{1 0 9}$ & $\mathbf{1 9}$ & $\mathbf{8}$ & $\mathrm{NIL}$ & $\mathbf{3 0 0}$ \\
\hline \multirow{2}{*}{$\begin{array}{l}\text { Loan \& } \\
\text { Advances }\end{array}$} & $\mathbf{5 4 . 6 6 \%}$ & $\mathbf{3 6 . 3 3 \%}$ & $\mathbf{6 . 3 3 \%}$ & $\mathbf{2 . 6 6 \%}$ & NIL & $\mathbf{1 0 0 \%}$ \\
\hline \multirow{2}{*}{$\begin{array}{l}\text { Subsidized food } \\
\text { facility }\end{array}$} & $\mathbf{4 7}$ & $\mathbf{1 0 3}$ & $\mathbf{6 4}$ & $\mathbf{5 3}$ & $\mathbf{3 3}$ & $\mathbf{3 0 0}$ \\
\hline \multirow{nyyyyyy}{*}{$\begin{array}{l}\text { Retirement } \\
\text { Benefits }\end{array}$} & $\mathbf{2 6 . 3 3 \%}$ & $\mathbf{3 4 . 3 3 \%}$ & $\mathbf{2 1 . 3 3 \%}$ & $\mathbf{1 7 . 6 6 \%}$ & $\mathbf{1 1 \%}$ & $\mathbf{1 0 0 \%}$ \\
\cline { 2 - 7 } & $\mathbf{3 7 . 3 3 \%}$ & $\mathbf{3 0 . 3 3 \%}$ & $\mathbf{1 8 . 3 3 \%}$ & $\mathbf{1 6 . 6 6 \%}$ & $\mathbf{8 . 3 3 \%}$ & $\mathbf{1 0 0 \%}$ \\
\hline
\end{tabular}

Source: Primary data 
The above table represents the satisfaction and dissatisfaction level of the labours those who are working under the said industries regarding welfare measures.

Leave Facility: It indicates that more than $15 \%$ of the respondents are dissatisfied where as $38.33 \%$ of the respondents are moderately satisfied with the leave facility of the industries.

Facility for children education: In this area, more than $54 \%$ respondents are highly dissatisfied, where as only $2.66 \% \%$ of our respondents are satisfied regarding facility for children education and even if a single respondent is highly satisfied.

Loan \& Advances: Only $17.66 \%$ of the respondents are satisfied regarding loan and advances provide by the industries. But, near about $34.33 \%$ of the respondents are dissatisfied regarding this loan and advances.

Subsidized food facility: It indicates that $30.33 \%$ of the respondents are dissatisfied where as only $8.33 \%$ of the respondents are highly satisfied with the subsidized food facility of the industries.

Retirement Benefits: It reveals more than $38 \%$ of the respondents are both highly dissatisfied and dissatisfied whereas, only $24.33 \%$ of the respondents are satisfied.

TABLE: 5 Job Interest \& Involvement Factor Which Influence Labour Productivity

\begin{tabular}{|c|c|c|c|c|c|c|}
\hline $\begin{array}{l}\text { Job interest } \\
\text { \& } \\
\text { involvement } \\
\text { factor } \\
\end{array}$ & $\begin{array}{l}\text { Highly } \\
\text { Dissatisfied }\end{array}$ & Dissatisfied & $\begin{array}{l}\text { Moderately } \\
\text { Satisfied }\end{array}$ & Satisfied & $\begin{array}{l}\text { Highly } \\
\text { Satisfied }\end{array}$ & Total \\
\hline \multirow[t]{2}{*}{ Job Security } & 42 & 83 & 131 & 27 & 17 & 300 \\
\hline & $14 \%$ & $27.66 \%$ & $43.66 \%$ & $9 \%$ & $5.66 \%$ & $100 \%$ \\
\hline \multirow{2}{*}{$\begin{array}{l}\text { Inter- } \\
\text { personal } \\
\text { relationship }\end{array}$} & 12 & 32 & 143 & 79 & 34 & 300 \\
\hline & $4 \%$ & $10.66 \%$ & $47.66 \%$ & $26.33 \%$ & $11.33 \%$ & $100 \%$ \\
\hline \multirow{2}{*}{$\begin{array}{l}\text { Relationship } \\
\text { with } \\
\text { Supervisor }\end{array}$} & 124 & 74 & 54 & 39 & 9 & 300 \\
\hline & $41.33 \%$ & $24.66 \%$ & $18 \%$ & $13 \%$ & $3 \%$ & $100 \%$ \\
\hline \multirow{2}{*}{$\begin{array}{l}\text { Working } \\
\text { Environment }\end{array}$} & 64 & 97 & 80 & 42 & 17 & 300 \\
\hline & $21.33 \%$ & 32.33\% & $26.66 \%$ & $14 \%$ & $5.66 \%$ & $100 \%$ \\
\hline \multirow{2}{*}{$\begin{array}{l}\text { Personal } \\
\text { Achievement } \\
\text { \& growth }\end{array}$} & 39 & 126 & 87 & 32 & 16 & 300 \\
\hline & $13 \%$ & $42 \%$ & $29 \%$ & $10.66 \%$ & $5.33 \%$ & $100 \%$ \\
\hline
\end{tabular}

\section{Source: Primary data}

The above table represents the satisfaction and dissatisfaction level of the labours those who are working under the said industries regarding their job interest $\&$ involvement factor.

Job Security: It shows $27.66 \%$ of respondents are dissatisfied where as $9 \%$ respondents are satisfied with job security provided by the said industries.

Inter-personal relationship: It denotes $10.66 \%$ of respondents are dissatisfied and a minimum of $26.33 \%$ respondents are satisfied with the inter-personal relationship

Relationship with Supervisor: It indicates that $41.33 \%$ of the respondents are highly dissatisfied where as only $3 \%$ of the respondents are highly satisfied with the relationship with the supervisor.

Working Environment: It reveals that near about $32.33 \%$ respondents are dissatisfied and only a minimum of $14 \%$ respondents are dissatisfied with the working environment.

Personal Achievement \& growth: On these criteria, more than 55\% respondents are both highly dissatisfied and dissatisfied and on the other hand 15\% respondents are satisfied with their personal achievement and growth in the industries. 


\section{Conclusion:}

Now, it is crystal clear from the above study that various factors are very much important to motivate the labours to improve their productivity and efficiency. There is no doubt about the direct and positive relationship between motivational factors as discussed above and labours' productivity level. In the state of Odisha, the handicraft and cottage industries are facing low level of growth only due to low labour productivity. In almost every section i.e. human resource policy, allowances, and labour welfare measures and in job interest and involvement, we may observe that labours are dissatisfied or discouraged.

The first essential step is to find out what motivational tools will in fact be effective in each particular situation. The workers of the said industries are positively affected toward higher productivity with the provision of better wage and salary structure, regular promotion, assurance of adequate job security and bonus for excellent performance as well as proper time to time training and education also. Nevertheless monetary incentives and rewards do not exert stronger influence on workers than any form of motivational factor. The organization should encourage initiative and creativity by allowing for some flexibility in application of rules and regulation. Finally, it may be viewed that the State government of Odisha should look after not only monetary reward or incentives of the workers but also the non monetary factors.

\section{Reference:}

[1] Dr.Sucharitha, Dr.J.U.Maheswar Reddy, and Dr.Reecharanjansingh(2012), 'The impact of flexible work arrangements in selected IT sector-an employee perspective', International Journal of Research in IT \& Management, Volume 2, Issue 2 PP $882-896$

[2] Dale S. Rose, Stuart D. Sidle and Kristin H. Griffith (2007) Organisational Research Methods, Volume10, Issue 2, PP 225-246.

[3] Gupta B. (1975) Labour Incentive in India of Iron and Steel Industry Research Abstract Quarterly, PP 171 - 176.

[4] Kalburgi ,Mohammed Javed and G.P ,Dinesh. (2010) "Motivation as a tool for productivity in Public sector unit" Asian Journal of Management Research PP 147-152

[5] Lawler E.E (2003), Treats people right. San Francisco: Jossey-Bass Inc.

[6] Mathew H.( 1983), 'Developing employment package attracting and retaining best employees', Management Decision, $28,6$.

[7] Navdeep Kumar1, Pankaj Garg(2011), 'Impact of motivational factors on employee's job satisfaction- A study on some selected organization in Punjab, India' ,Asian Journal of Management Research, Volume 2 Issue 1, 2011 PP 672-683

[8] Sharma A.M. (1991) Understanding Wage System, New Delhi, Himalaya Publications.

[9] Wadhwa ,Daljeet Singh, Verghese ,Manoj, Wadhwa ,Dalvinder Singh (2011), 'A Study on Factors Influencing Employee Job Satisfaction -A Study in Cement Industry of Chhattisgarh', International Journal of Management \& Business Studies Vol. 1, Issue 3, PP 109-111 